\title{
Zastosowanie krótko-czasowej transformaty Fouriera do analizy procesu spawania elektrodą otuloną
}

\author{
Application of short-time Fourier transform \\ to analysis of welding process using coated electrode
}

\section{Streszczenie}

Jakość złączy spawanych uzależniona jest od wielu czynników, w tym od właściwości spawalniczych elektrod otulonych, rozumia-nych jako ogół cech umożliwiających prowadzenie procesu spawania w sposób stabilny i równomierny.

W artykule opisano wyniki badań nad wykorzystaniem krótko-czasowej analizy Fourier'a do opisu rzeczywistych sygnałów napięcia i prądu spawania w kontekście oceny stabilno-ści procesu spawania elektrodą otuloną. W tym celu przeprowadzono szereg prób spawania podczas których rejestrowano sygnały prądowonapięciowe elektrod o różnych właściwościach spawalniczych.

Z przeprowadzonej analizy wynika, analiza czasowoczęstotliwościowa jest narzędziem pozwalającym na dokładniejszy opis zjawisk zachodzących podczas spawania, znacznie wykraczającym poza typową transformatę Fourier'a FFT.

Słowa kluczowe: transformata Fouriera, spawanie, elektroda otulona

\section{Abstract}

Stable and uniform process of welding (weldability) is one of the most important factors, which crucially determines properties of welded joints. For this reason evaluation of weldability of each lot of electrodes during manufacturing process is extremely important. Traditionally tests of weldability are carried out by experienced welder based on detailed criteria given by the manufacturer for each type of electrode. Anyway evaluation process and final decision given by the welder is subjective by nature and can be somehow by failed.

Authors has been conducting research of using actual digital welding current and voltage signals to the description and analysis of the welding process and stability itself.

In the article results of the Short Fourier Transform analysis for evaluation of current and voltage signals were presented. Results of spectra analysis prove that evaluation of welding process of MMAW is possible based on an observation of values of spectra components generated by the circuit 'welding electrode - welding source'.

Keywords: Fourier transform, welding, coated electrode

\begin{abstract}
Wstęp
Jednym z najważniejszych czynników wpływających na stabilny i jednorodny proces spawania a zatem i jakość złączy spawanych są właściwości spawalnicze elektrod otulonych. Stabilny proces umożliwia uzyskanie spoiny o poprawnej geometrii, praktycznie nie zmieniającej się na całej długości złącza szerokości i wysokości lica oraz głębokości wtopienia, co w rezultacie znacznie zwiększa prawdopodobieństwo uzyskania złącza o wymaganych właściwościach mechanicznych. Opisana zależność określana jest w literaturze mianem stabilności technologicznej [2,3]. Podczas procesu produkcyjnego $\mathrm{w}$ ramach odbioru końcowego poszczególne partie elektrod poddawane są kontroli właściwości spawalniczych w oparciu o szczegółowe kryteria oceny określone dla poszczególnych gatunków elektrod.
\end{abstract}

Badania elektrod obejmują próbę spawalności uwzględniającą ocenę takich parametrów jak:

- zdolność stabilnego jarzenia się łuku spawalniczego,

- sposób przenoszenia ciekłego metalu do jeziorka spoiny,

- zachowania się płynnego żużla podczas spawania,

- równomierne topienie się elektrody (rdzenia oraz otuliny),

- wielkość rozprysku,

- zajarzalność pierwotna i wtórna,

- odbijalność żużla oraz pozostałości żużla na licu spoiny. Kontrola właściwości spawalniczych elektrod prowadzona jest na ostatnim etapie procesu produkcyjnego przez spawacza klasyfikatora. Trafność oceny w głównej mierze uzależniona jest od doświadczenia i wyczucia spawacza. Ocena spawacza klasyfikatora z natury jest oceną subiektywną, ale jak dotąd jest to jedyny sposób stosowany w praktyce przemysłowej [6].

Dr hab. inż. Marek Fidali - Politechnika Śląska, mgr inż. Benedykt Ślązak - Lincoln Electric Bester. 
Jednym z narzędzi, które mogłyby posłużyć w przyszłości do wspomagania procesu oceny właściwości spawalniczych mogłyby być systemy oparte o analizę rzeczywistych sygnałów napięcia i prądu spawania, które są źródłem wielu cennych informacji na temat stabilności procesu spawania $[4,10,13,14]$. Przetworzone do postaci cyfrowej sygnały napięcia i prądu można poddać analizie wykorzystując w tym celu różnorodne metody przetwarzania i analizy sygnałów [10,12].

Analiza sygnałów napięciowo-prądowych, znajduje coraz szersze zastosowanie w zagadnieniach monitorowania, diagnozowania i kontroli procesu spawania [5,9,10,15]. Można tutaj wskazać głównie aplikacje spawania półautomatycznego w osłonach gazowych [1 1,14]. W przypadku spawania ręcznego elektrodami otulonymi analiza sygnałów napięciowo-prądowych, jak dotąd, stosowana jest w ograniczonym zakresie, co wiąże się z niedoskonałością systemów monitorujących i brakiem jednoznacznych kryteriów oceny $[5,6]$.

W artykule przedstawiono wybrane wyniki badań dotyczących analizy sygnałów prądu i napięcia w dziedzinie czasu i częstotliwości [7\%9]. Badania mają na celu opracowanie metodyki pozwalającej na ocenę jakości elektrod otulonych w zakresie właściwości spawalniczych bez udziału spawacza klasyfikatora.

\section{Analiza czasowo-częstotliwościowa sygnałów}

Przebiegi prądu i napięcia spawania można uznać za sygnały niestacjonarne zawierające składowe o charakterze przejściowym i losowym. Do analizy sygnałów niestacjonarnych nadają się dobrze tzw. czasowo-częstotliwościowe metody analizy sygnałów pozwalające rozpatrywać sygnał nie tylko z punktu widzenia obecności charakterystycznych składowych częstotliwościowych tak jak to ma miejsce w przypadku klasycznej analizy Furierowskiej ale również z punktu widzenia chwil czasu, w których składowe te występują [8]. Z pośród wielu metod czasowo-częstotliwościowej analizy sygnałów [1] można wymienić krótko-czasową analizę Fouriera (STFT - Short Time Fourier Transform).

Krótko-czasowa analiza sygnału zakłada możliwość podziału sygnału na krótkie odcinki czasu, w których sygnał można uznać za stacjonarny. Metoda ta jest realizowana w następujących krokach:

- podział sygnału na jego stacjonarne podrealizacje,

- wyznaczenie widm kolejnych podrealizacji,

- uporządkowanie widm w czasie i ich graficzna reprezentacja w postaci trójwymiarowego wykresu kaskadowego lub dwuwymiarowej mapy rozkładu wartości składowych widmowych zwanej spektrogramem.

Wyznaczanie widm krótkoczasowych można opisać następującym wyrażeniem:

$$
S(t, f)=\int_{-\infty}^{\infty} x(t) w(\tau-t) e^{-j f t} d \tau
$$

Wynika z niego, że podrealizacja sygnału x(t) jest wynikiem mnożenia jego realizacji przez funkcję okna w( $\tau$ ), które jest przesuwane w czasie t. Ocena sygnału z zastosowaniem tej metody może być realizowana dla odcinków czasu zachodzących na siebie i rozłącznych. $S(t, f)$ może być interpretowane jako wartość transformaty sygnału $x(t) w$ chwili t dla dyskretnej częstotliwości f.

Wyznaczenie widmowej charakterystyki sygnału metodą widm krótkoczasowych może być związane z koniecznością określenia:

- sposobu podziału sygnału na podrealizacje,
- funkcji okna,

- określenia długości podrealizacji sygnału,

- określeniem sposobu wyznaczenia widma podrealizacji sygnału.

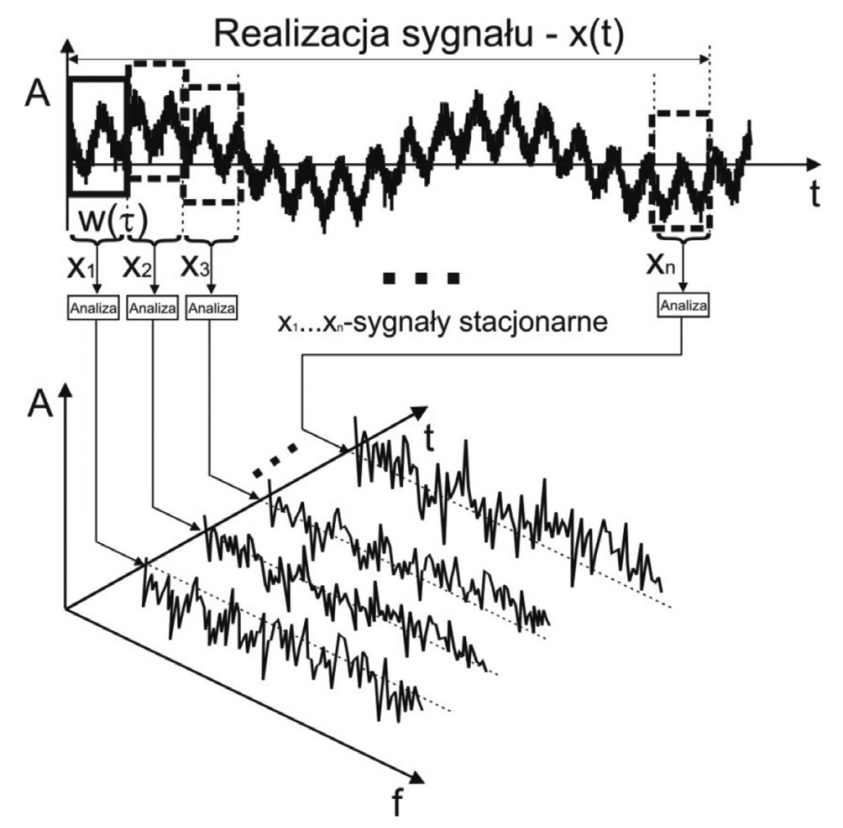

Rys. 1. Sposób realizacji, krótkoczasowej analizy częstotliwościowej [1] Fig. 1. Idea of short-time Fourier analysis [1]

\section{Cel i zakres badań}

Celem prowadzonych badań jest sprawdzenie możliwości zastosowania analizy czasowo-częstotliwościowej do opisu i analizy sygnałów napięciowo-prądowych procesu spawania elektrodą otuloną. Badania prowadzono na sygnałach prądu i napięcia zarejestrowanych podczas prób spawania wykonanych w Samodzielnym Zakładzie Spawalnictwa Wydziału Inżynierii Mechanicznej i Informatyki Politechniki Częstochowskiej. Przetwarzanie i analizę sygnałów przeprowadzono przy współpracy z Instytutem Podstaw Konstrukcji Maszyn, Wydziału Mechanicznego Technologicznego Politechniki Śląskiej w Gliwicach.

Próby spawania prowadzono na stanowisku wyposażonym w wielokanałowy komputerowy układ pomiaru i rejestracji sygnałów prądu i napięcia spawania typu LC-011/16, w skład którego wchodził układ filtrujący oparty na galwanicznym separatorze zakłóceń. Podczas badań zastosowano inwertorowe źródło prądu stałego typu FalTig 200.

Do badań wybrano elektrody w gatunku Omnia 46 (E 380 R1 1 wg PN-EN ISO 2560-A) oraz Supra (E320 RC11 wg PNEN ISO 2560-A), obie o wymiarach $\varnothing 3,2 \times 350 \mathrm{~mm}$

Obok elektrod pierwszego gatunku zostały zbadane również elektrody wadliwe o wyraźnie gorszej spawalności; w partii wadliwej zastosowano szkło wodne sodowe $\mathrm{Na}_{2} \mathrm{O}$ zamiast tradycyjnie stosowanego dla tej grupy elektrod szkła potasowego $\mathrm{K}_{2} \mathrm{O}$ (na którym zostały wyprodukowane elektrody właściwe).

Dla każdej grupy elektrod wykonano serię pomiarów wartości chwilowych przebiegów napięcia i prądu w czasie rzeczywistym dla trzech zakresów prądu spawania 90, 110 i 130A. Napoiny układano w sposób ręczny w pozycji podolnej na metalicznie czystych próbkach

o wymiarach $150 \times 80 \times 5 \mathrm{~mm}$ ze stali w gatunku S235JR wg PN-EN 10027-1:1994; prędkość spawana mieściła się w zakresie $20-25 \mathrm{~cm} / \mathrm{min}$, kąt pochylenia elektrody do materiału wynosił ok. $70^{\circ}$. Próby spawalności wykonano dla obu polaryzjacji DC+ oraz DC-. 


\section{Analiza wyników badań}

W ramach badań krótkoczasowej analizie częstotliwościowej poddano sygnały prądu i napięcia zarejestrowane w trakcie spawania elektrodami otulonymi. Podczas analizy stosowano okno prostokątne o szerokości 128 próbek. Każdy segment sygnału zachodził na poprzedni co 64 próbki. Dla każdej podrealizacji sygnału estymowano gęstość widmową mocy przy założonej liczba prążków widma wynoszącej 1024.

W efekcie analizy krótkoczasowej otrzymano szereg spektrogramów, które poddano wnikliwej analizie, której celem była odpowiedź na następujące pytania:

- jakie nowe informacje w stosunku do klasycznej analizy Furierowskiej wnosi analiza czasowo-częstotliwościowa?

- czy możliwa jest ocena przebiegu spawania w czasie i detekcja istotnych zakłóceń procesu?

Analiza danych polegała na wzrokowym porównaniu spektrogramów sygnałów prądu i napięcia otrzymanych w trakcie spawania różnymi elektrodami o różnej jakości, z różną polaryzacją i różnymi parametrami spawania.

\section{Ocena spektrogramów}

z punktu widzenia zmiany polaryzacji źródła

Spawanie z polaryzacją ujemną elektrodą Omnia słabej jakości (NOK) powoduje, że w spektrogramach sygnału prądowego (tabl. I) uwydatniła się składowa ok. $1250 \mathrm{~Hz}$ a osłabła składowa ok. $1700 \mathrm{~Hz}$ w stosunku do spektrogramu uzyskanego na podstawie sygnału prądowego zarejestrowanego podczas spawania elektrodą Omnia dobrej jakości (OK.).

Można zauważyć, że sytuacja odwraca się gdy zmieniona została polaryzacja na dodatnią. W tym przypadku przy elektrodzie wadliwej składowa ok. $1250 \mathrm{~Hz}$ osłabia się natomiast składowa ok. $1700 \mathrm{~Hz}$ wzmacnia. Prawidłowość ta można zaobserwować dla wszystkich wartości prądów spawania. W przypadku spektrogramów sygnału napięciowego wskazane wcześniej składowe częstotliwościowe zachowują się w podobny sposób. Spektrogramy sygnału napięciowego zarejestrowanego podczas spawania elektrodą Omnia pozwalają rozróżnić zmianę polaryzacji szczególnie przy wyższych prądach spawania. Na spektrogramach sygnału napięciowego zarejestrowanego podczas spawania z polaryzacją dodatnią widać wzrost amplitud i zagęszczenie składowych niskoczęstotliwościowych w trakcie całego procesu wykonywania złącza.

Tablica I. Przykładowe spektrogramy wyznaczone dla sygnałów prądowych zarejestrowanych podczas spawania elektrodami Omnia przy różnej polaryzacji i różnych prądach spawania

Table I. Examplary spectrograms obtained for current signals recorded during welding of Omnia electrode with different polarizations and current values

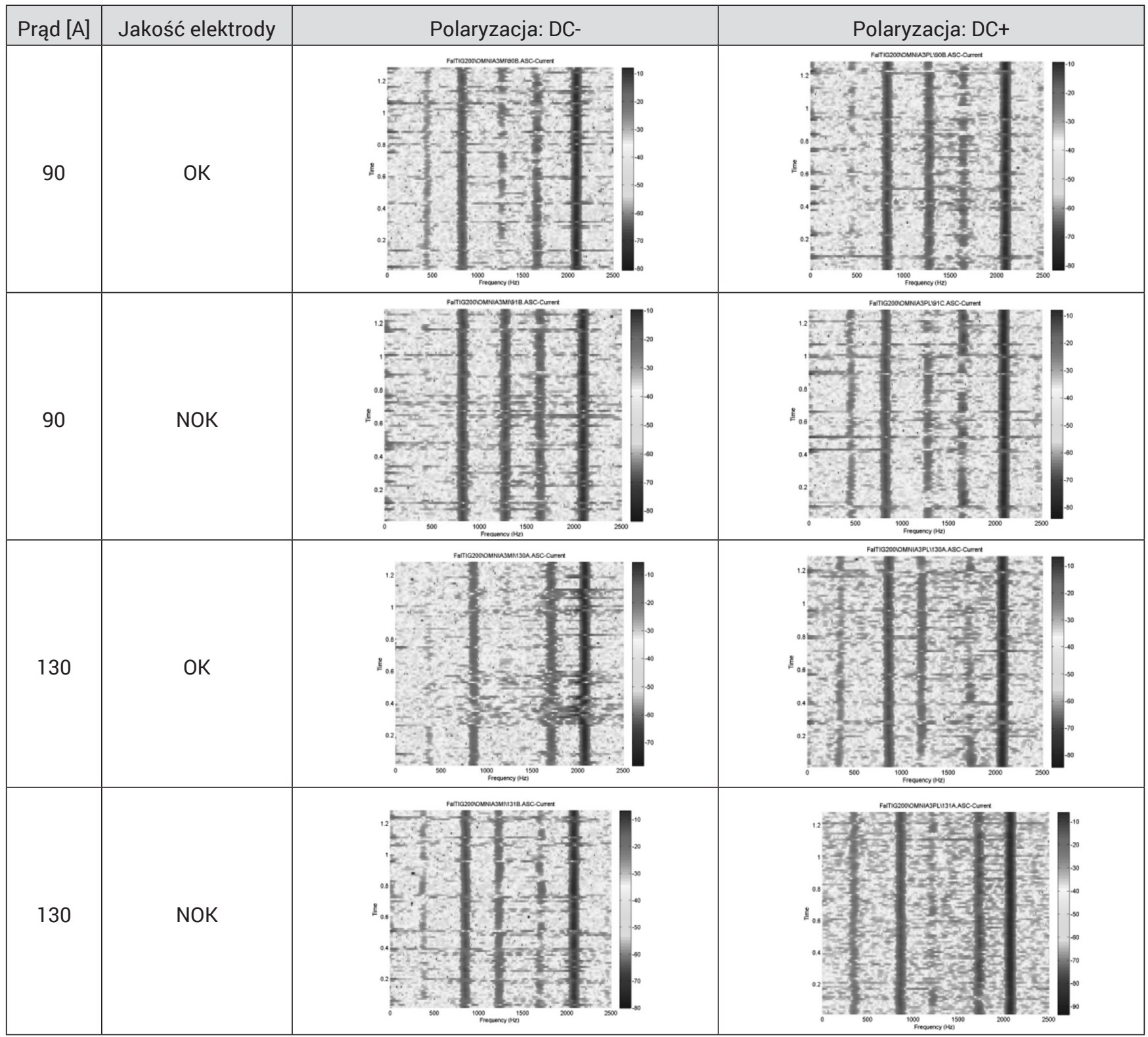


Tablica II. Przykładowe spektrogramy wyznaczone dla sygnałów napięciowych zarejestrowanych podczas spawania elektrodami Omnia przy różnej polaryzacji i różnych prądach spawania

Table II. Examplary spectrograms obtained for voltage signals recorded during welding of Omnia electrode with different polarizations and current values

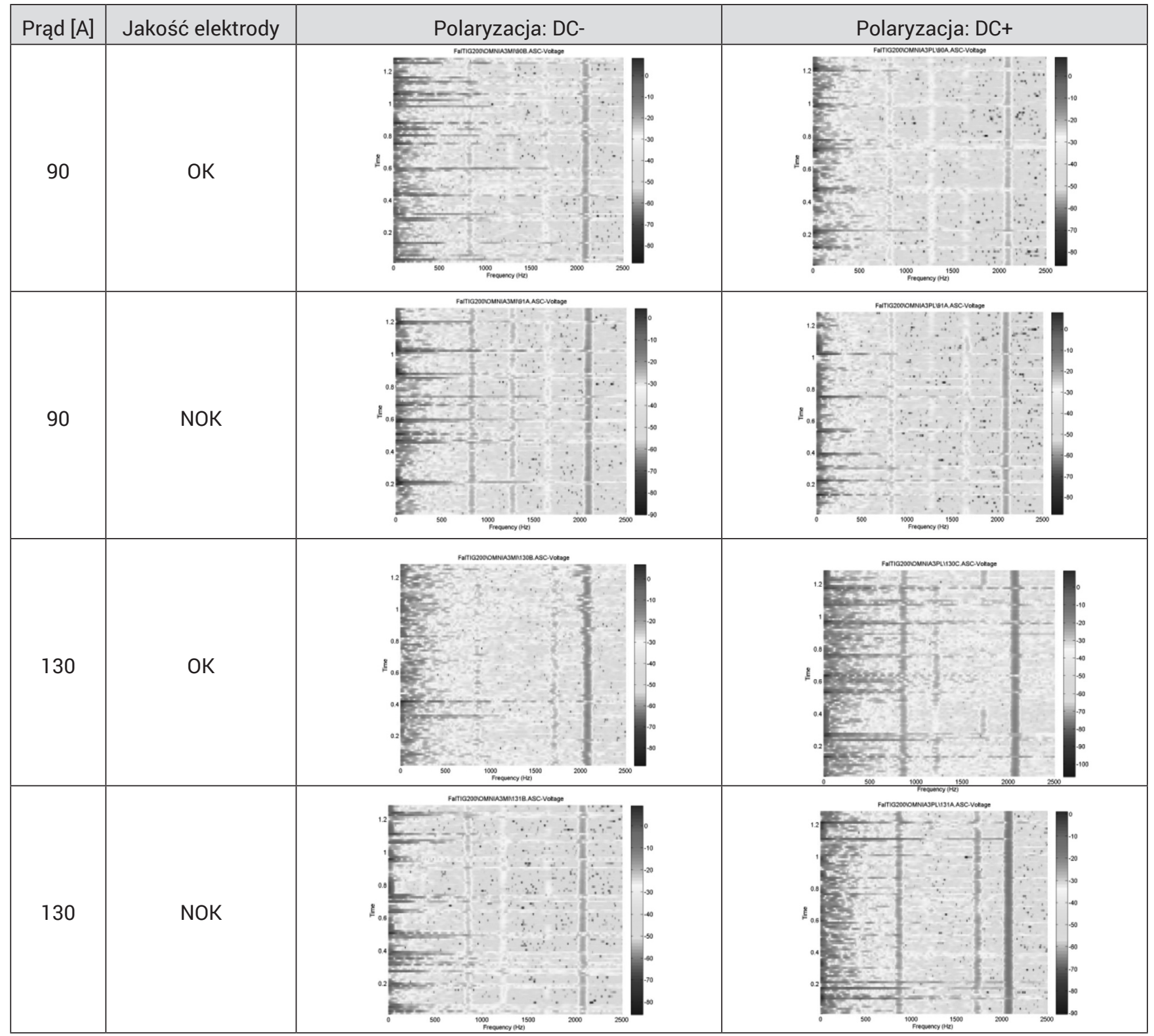

W przypadku elektrod Supra, na podstawie spektrogramów sygnału prądowego trudno jest jednoznacznie zidentyfikować zmiany polaryzacji i rozróżnić elektrody o różnej jakości. Jednak w przypadku spektrogramów sygnałów napięciowych możliwe jest rozróżnienie słabej jakościowo elektrody na podstawie składowej ok. $1700 \mathrm{~Hz}$, której amplituda wyraźnie maleje gdy stosuje się wadliwa elektrodę szczególnie przy dużych prądach spawania. Również przy dużym prądzie spawania przy polaryzacji dodatniej składowe niskoczęstotliwościowe posiadają wyższą amplitudę i występują częściej niż w przypadku polaryzacji ujemnej.

\section{Ocena spektrogramów}

z punktu widzenia rodzaju stosowanej elektrody

Spektrogramy sygnałów prądowych i napięciowych wykorzystano do identyfikacji rodzaju i jakości zastosowanej elektrody. W tablicach III i IV zaprezentowano przykładowe spektrogramy dla sygnałów prąd i napięcia. Dostrzeżono różnice głównie w składowych częstotliwościowych. Dla elektrody Omnia dobrej jakości stosowanej do spawania z polaryzacją ujemną w spektrogramach sygnału prądowego składowa ok $1250 \mathrm{~Hz}$ występowała znacznie mniej intensywniej niż w przypadku elektrody Supra stosowanej do spawania w tych samych warunkach. Elektroda Omnia złej jakości dawała podobne sygnatury widmowe w spektrogramach jak w przypadku elektrody Supra o złej jakości. Porównanie spektrogramów prądu spawania dla dobrej i złej jakościowo elektrody Supra pozwoliło zidentyfikować różnice głównie na podstawie składowej częstotliwościowej około $500 \mathrm{~Hz}$ w przypadku wadliwej elektrody wartości tej składowej wzrastały. Subiektywna ocena spektrogramów dla elektrody Supra pozwala również stwierdzić, 
że dla mniejszych prądów spawania w spektrogramie widoczna jest większa ilość składowych przypadkowych pojawiających w czasie spawania.

W przypadku spawania z polaryzacją dodatnią różnice miedzy elektrodami Omnia i Supra w spektrogramach dostrzegalne są w przypadku wyższych prądów spawania 110 i 130A głównie dla elektrod o złej jakości. W przypadku wadliwej elektrody Omnia składowa ok. $1750 \mathrm{~Hz}$ ma większą amplitudę w porównani z elektrodą Supra. Spektrogramy prądowe dla polaryzacji dodatniej nie pozwalają w jednoznaczny sposób wykryć różnic między elektrodami dobrymi i złymi w obrębie jednego rodzaju elektrody.

W przypadków spektrogramów napięcia dla polaryzacji ujemnej również dostrzegalne są różnice między dobrymi jakościowo elektrodami Omnia i Supra w składowej o częstotliwości ok $1250 \mathrm{~Hz}$, która jest intensywniejsza dla elektrody Supra. Składowa ta również pozwala rozróżniać dobre i złe jakościowo elektrody Omnia, gdyż dla elektrody o gorszej jakości składowa ta objawia się wyższą amplitudą niż w przypadku elektrody dobrej jakości. Podobnie jak w przypadku spektrogramów sygnałów prądowych nie można w jednoznaczny sposób wykryć różnic między dobrymi i złymi elektrodami Supra.

Spektrogramy sygnałów napięciowych pozyskanych podczas spawania z polaryzacją dodatnią pozwalają na rozróżnianie dobrych i złych jakościowo elektrod Omnia i Supra. Pozwala na to składowa $1750 \mathrm{~Hz}$. W spektrogramach dla dobrych jakościowo elektrod Omnia składowa ta jest słabsza niż w przypadku złych jakościowo elektrod Omnia i dobrych jakościowo elektrod Supra. W przypadku złych jakościowo elektrod Omnia składowa ta jest bardziej intensywna w porównaniu do złych jakościowo elektrod Supra.

Tablica III. Przykładowe spektrogramy wyznaczone dla sygnałów prądowych zarejestrowanych podczas spawania elektrodami Omnia i Supra przy polaryzacji ujemnej oraz z różnymi prądami spawania

Table III. Examplary spectrograms obtained for current signals acquired during welding of Omnia and Supra electrodes with negative polarization and different current values

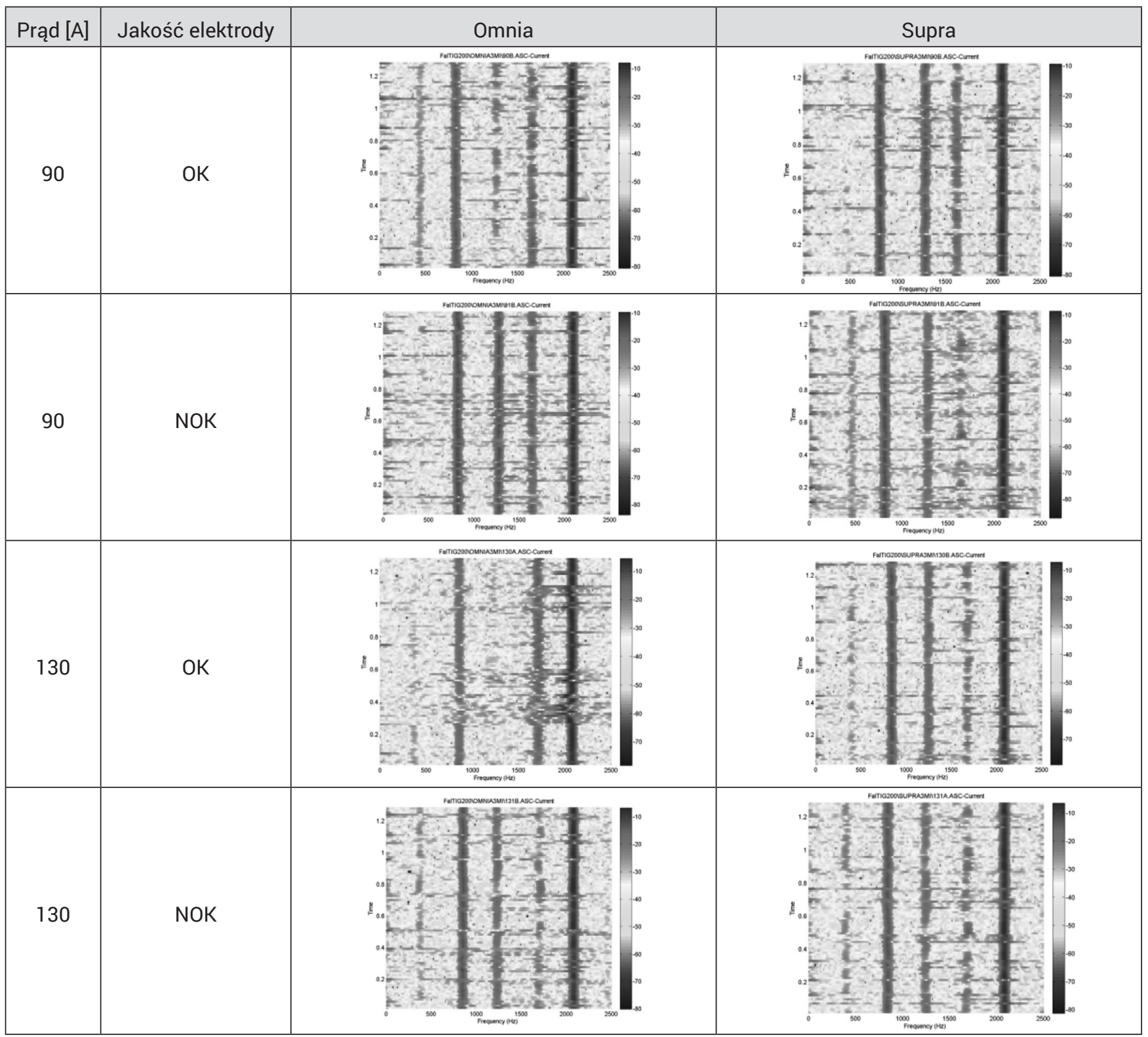


Tablica IV. Przykładowe spektrogramy wyznaczone dla sygnałów napięciowych zarejestrowanych podczas spawania elektrodami Omnia i Supra przy polaryzacji ujemnej oraz z różnymi prądami spawania

Table IV. Examplary spectrograms obtained for voltage signals acquired during welding of Omnia and Supra electrodes with negative polarization and different current values

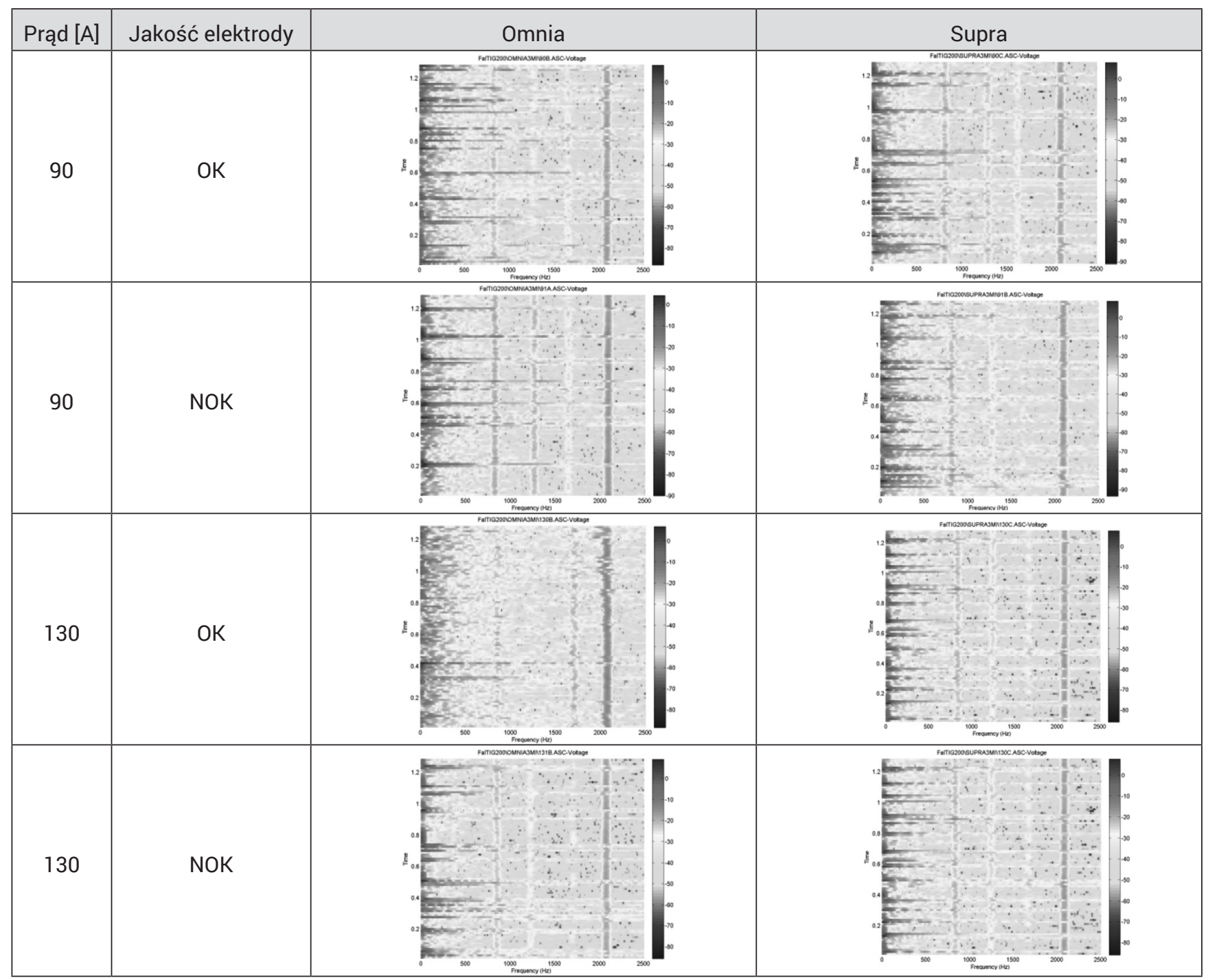

\section{Podsumowanie}

W artykule przedstawiono wyniki analizy czasowo-częstotliwościowej sygnałów prądowo-napięciowych zarejestrowanych podczas spawania różnymi elektrodami przy różnych parametrach spawania. Celem badań była ocena właściwości spawalniczych elektrod otulonych. Spektrogramy wyznaczone podczas analizy-czasowo częstotliwościowej pozwalają na podstawie charakterystycznych wartości składowych częstotliwościowych identyfikować elektrody o gorszej jakości oraz wykrywać rodzaj polaryzacji stosowanej podczas spawania. Praktyczne wykorzystanie spektrogramów do kontroli jakości elektrod wymaga zdefiniowania wskaźnika widmowej oceny jakości co będzie przedmiotem dalszych badań. Dzięki uwzględnieniu osi czasu na podstawie spektrogramów możliwe jest również wykrywanie niestabilności przebiegu procesu spawania wywołanymi błędami spawacza i/lub nieprawidłowym przygotowaniem krawędzi elementów spawanych. Wydaje się, że spektrogramy mogą być źródłem informacji przydatnych przy ocenie umiejętności spawacza oraz jakości przygotowania krawędzi spawanych elementów. Weryfikacja tych tez wymaga przeprowadzenia dodatkowych badań. Wyniki przedstawione powyżej oraz wcześniejsze badania wskazują, że zastosowanie wybranych metod oceny sygnałów prądowo-napięciowych może znaleźć zastosowanie przy opracowaniu skomputeryzowanego systemu wspomagającego ocenę spawalności elektrod otulonych

\section{Literatura}

[1] A.Timofiejczuk: Metody analizy sygnałów niestacjonarnych. Gliwice 2004.

[2] E. Tasak, A. Ziewiec: Spawalność Materiałów Konstrukcyjnych, Wydawnictwo JAK 2009.

[3] E. Dobaj: Maszyny i urządzenia spawalnicze, WNT 1998.

[4 M. Węglowski, A. Kolasa, P. Cegielski: Ocena stabilności procesu ręcznego spawania łukowego elektrodami otulonymi, Przegląd Spawalnictwa, 1/2006.

[5] B Ślązak, J. Słania: Badania porównawcze elektrod otulonych wysokostopowych ERWS 19-9 L produkowanych przy zastosowaniu nowego szkła wodnego modyfikowanego tlenkiem litu, Biuletyn Instytutu Spawalnictwa $\mathrm{Nr} 6 / 2006$.

[6] K. Luksa: Diagnozowanie procesu spawania GMA ze zwarciowym przenoszeniem metalu przez łuk. Przegląd Spawalnictwa, nr 4-5/2005.

[7] R.G. Lyons: Wprowadzenie do cyfrowego przetwarzania sygnałów, Wydawnictwo Komunikacji i Łączności 2006.

[8] R. Bracewell: Przekształcenie Fouriera i jego zastosowanie, WNT 1965
[9] J. Słania: Wykorzystanie transformacji Fourier'a do analizy procesu spawania metodą MAG łukiem impulsowym, Biuletyn Instytutu Spawalnictwa $\mathrm{Nr} 1 / 1997$.

[10] Quinn T.P., Smith C., McCowan C.N., Blachowiak E., Madigan R.B. Arc sensing for defects in constant-voltage gas metal arc welding, WeIding Journal, Vol. 78, No. 9, 1999, pp. 322-328.

[11] P. Jiluan, Arc Welding Control, Woodhead Publishing Ltd. (2003).

[12] C.S. Wu et al: Real-time sensing and monitoring in robotic gas metal arc welding. Measurement Science and Technology. vol. 18, no. 1, 2007303.

[13] D. Rehfeldt, A. Bollmann: Using statistical signal analysis for analyzing and monitoring GMAW-processes. IIW Latin American Regional Welding Congress Vol. 2, Rio de Janeiro, Brazil; 4-10 Apr. 1992. pp. 839-844. 1992

[14] M. Suban, J. Tusek: Methods for the determination of arc stability, Journal of Materials Processing Technology, Volumes 143-144, Proceedings of the International Conference on the Advanced Materials Processing Technology, 2001., 20 December 2003, Pages 430-437

[15] S. Adolfsson, A. Bahrami, G. Bolmsjö, I. Claesson: On-Line Quality Monitoring in Short-Circuit Gas Metal Arc Welding. Welding Journal 782 1999, pp. 59-78. 